\title{
Nanostructures and Adhesion in Natural Rubber: New Era for a Classic
}

\author{
Márcia M. Rippel and Fernando Galembeck* \\ Instituto de Química, Universidade Estadual de Campinas, CP 6154, 13083-970 Campinas-SP, Brazil
}

\begin{abstract}
A borracha natural é obtida da Hevea brasiliensis, uma árvore nativa da floresta amazônica. Ela tem tido grande importância econômica há mais de 150 anos, sendo uma rica fonte de aprendizagem sobre polímeros e materiais poliméricos. Suas notáveis propriedades e vantagens sobre borrachas sintéticas atraíram a atenção de muitos pesquisadores que identificaram várias singularidades estruturais. Hoje, está claro que a borracha natural é um complexo material nanoestruturado, formado por poli(cis-1,4-isopreno), proteínas, fosfolipídios e vários componentes minerais minoritários. A contribuição dos autores para esta aprendizagem está resenhada neste artigo e abriu o caminho para o desenvolvimento de novos nanocompósitos, usando processos suaves e "verdes", dentro de um novo paradigma para a fabricação de materiais derivados de fontes renováveis.
\end{abstract}

Natural rubber is obtained from Hevea brasiliensis, a tree that is native from the Amazon forest. It has been economically important for the past 150 years and it has also been a rich source of learning on polymers and polymeric materials. Its outstanding properties and advantages over synthetic rubbers have attracted the attention of many researchers that unraveled many contributing factors. Now, it is clear that natural rubber is a complex nanostructured material formed by poly (cis1,4-isoprene), protein, phospholipids and a host of mineral minor components. Contribution of the authors to knowledge on natural rubber is reviewed in this paper and it opened the way to develop a host of new nanocomposites, using mild, "green" processes, within a new paradigm for the fabrication of materials derived from renewable sources.

Keywords: natural rubber, latex, nanocomposites, clays, electrostatic adhesion, blends, renewable raw materials

\section{Introduction}

Natural rubber is usually described as poly(cis-1,4isoprene), a natural product that also contains minority but relevant components, especially proteins, carbohydrates, phospholipids and inorganic compounds in variable amounts. Its unique properties are often assigned to the large molar weight of the base polymer as well as to its chemical singularities. Nearly 2500 plant species produce latex, but the Amazon forest species Hevea brasiliensis is the only commercially relevant source of natural rubber. ${ }^{1}$ Table 1 shows other plants that produce latex and can thus be seen as alternatives sources for rubber. ${ }^{1-5}$

Natural rubber is a strategic material, because it cannot be replaced by synthetic rubbers, in some important applications, due to its outstanding elasticity, resilience, flexibility at low temperatures, resistance to abrasion, to impact and corrosion, facile adhesion to textiles, steel and

*e-mail: fernagal@iqm.unicamp.br to its impermeability, insulating properties and ability to disperse heat. When compared to synthetic rubbers with similar performance, its price is often advantageous. ${ }^{1,6,7}$

It is currently used in more than 50 thousand different products: adhesives, tyres, surgical gloves, health equipment and accessories, condoms, coatings and floor covering. . $^{1,6,7}$ Some current circumstances have contributed to increasing demand of natural rubber: ${ }^{1}(i)$ The uncertainty on oil price and availability coupled to the pressure for oil replacement; (ii) increased demand in countries with large populations and growing markets; ${ }^{8,9}$ (iii) substitution of palm trees for rubber trees in Malaysia, due to energy demand.

Nevertheless, the production process is still manpowerintensive decreasing its attractiveness whenever economic growth leads to demand for higher wages. Rubber tree plantations are always subject to the menace of the fungus Microcyclus ulei, a pest that destroyed plantations in the Amazon. ${ }^{1,10}$

Beyond the rubber tree, the guaiule shrub (Parthenium argentatum) and Russian dandelion (Taraxacum koksaghyz) 
Table 1. Sources of natural rubber

\begin{tabular}{|c|c|c|c|c|}
\hline Source & Origin & $\begin{array}{l}\text { Latex solids content / (\%) } \\
\text { (average molar weight / } \mathrm{kDa} \text { ) }\end{array}$ & $\begin{array}{l}\text { Production / ton. year }{ }^{-1} \\
\text { (year) }\end{array}$ & $\begin{array}{l}\text { Productivity / } \\
\left(\mathrm{kg} \mathrm{ha}^{-1} \text { year }^{-1}\right)\end{array}$ \\
\hline $\begin{array}{l}\text { Hevea brasiliensis } \\
\text { (rubber tree) }\end{array}$ & $\begin{array}{l}\text { Brazil, but the larger } \\
\text { producers are in Asia }\end{array}$ & $30-50(1310)$ & $9.876 .000(2008)$ & $500-3000$ \\
\hline $\begin{array}{l}\text { Parthenium argentatum } \\
\text { (guaiule) }\end{array}$ & México and US Southwest & $3-12(1280)$ & $\begin{array}{c}10.000(1910) \\
2.600 .000(1988)\end{array}$ & $300-2000$ \\
\hline Manihot glaziovii (maniçoba) & Brazil & $3-12(1000-1500)$ & -- & -- \\
\hline $\begin{array}{l}\text { Ficus elastica, F. ovata, } \\
\text { F. pumila, F. volgelii } \\
\text { (fig tree or indian rubber) }\end{array}$ & Nigeria & $15-28(--)$ & -- & -- \\
\hline $\begin{array}{l}\text { Taraxacum koksaghyz } \\
\text { (Russian dandelion) }\end{array}$ & Russia & Up to $30(2180)$ & $3000(1943)$ & $150-500$ \\
\hline $\begin{array}{l}\text { Solidago altissima } \\
\text { (goldenrod) }\end{array}$ & United States & $5-12$ in the root $(160-240)$ & -- & $110-155$ \\
\hline
\end{tabular}

produce latex with high molar weight polymer and received some attention from researchers and research planners, especially during II World War. Solidago altissima (goldenrod) was comercially explored, in the first half of 20th century, but after 1945 Hevea plantations in Asia became again accessible to international trade and its alternatives were almost abandoned. New efforts were recently publicized. ${ }^{11-13}$

Natural rubber latex was already collected by Brazilian Indians and dried over wood fire, producing artifacts long before the arrival of the Portuguese in $1500 .{ }^{14}$ Commercial exploration of natural rubber grew during the second half of 19th century as an Amazonian monopoly, reaching its apogee between 1905 and 1912 when car industry was fast growing in the US and Europe. Rubber was then the basis of the economy in the Brazilian North and it was also the largest Brazilian export good, attracting to the states of Pará and Amazon many British, German and American companies. ${ }^{15}$ For more than half-century of rubber economic bonanza, there was no significant effort for the development of agricultural and industrial technology for rubber production.

Since natural rubber was then the only raw material for tires, it acquired great economic and strategic importance that led British companies to create plantations in the then Asian colonies. Rubber trees developed very well as an exotic species, free from the Microcyclus ulei pest fungus, especially in Malaysia that soon became the dominant producer. Meanwhile, the primitive production system used in Brazil led the Amazon region into an economic crisis, aggravated by strong social tension between land-owners, rubber traders and the over-exploited "seringueiros". In Asia, research created powerful agricultural techniques and highly productive rubber-tree clones. Thailand and Indonesia are currently the largest producers in the world, contributing $27 \%$ and $29 \%$ of global production, respectively. Brazil that once held the rubber monopoly is now the $9^{\text {th }}$ producer ( $c a .1 \%$ only) and is a net natural rubber importer for its industry. ${ }^{8,16,17}$

In Brazil, consumption currently grows $6 \%$ per year, above the $4 \%$ world average, probably due to the fast growth of the car industry. For this reason, natural rubber importation currently grows $8 \%$ per year. Brazilian plantations are concentrated in the states of São Paulo (34\%), Bahia (15\%), Mato Grosso (29\%), Espírito Santo (4.7\%), Minas Gerais (2.9\%) and Goiás $(2.4 \%){ }^{8}$

Today, the role of the Amazon region in natural rubber development is largely as a genome bank.

\subsection{The "mistery" of natural rubber: nanostructures}

The origin of outstanding properties of natural rubber, as compared to any synthetic rubber, has intrigued many authors, and it was discussed by Tanaka. ${ }^{18}$ Natural rubber latex from $H$. brasiliensis is a colloidal polydispersion in which negatively charged particles are suspended in a serum. The major particle groups are the rubber particles, lutoids and the Frey-Wyssling complexes. Latex contains a large number of chemical compounds from $\mathrm{P}, \mathrm{C}, \mathrm{N}, \mathrm{O}$, $\mathrm{S}, \mathrm{Ca}, \mathrm{K}, \mathrm{Mg}, \mathrm{Cu}$ and $\mathrm{Fe}$, either due their role in latex biosynthesis or just because they are absorbed from the soil. ${ }^{19}$

The particle diameter of rubber particles is between 5 and 3,000 $\mathrm{nm}$, and they are surrounded by a complex mixture of proteins, lipids, and long-chain fatty acids, which impart negative charge. The rubber is soluble in many solvents but there is usually an insoluble gel fraction that increases with storage, analogous to the storage hardening observed in the dry rubber. Carboxylate and ester groups are associated with the rubber chains as described by Burfield ${ }^{20}$ and Kawahara, ${ }^{21}$ respectively. 
The former authors proposed carboxylate reaction with added cations $\left(\mathrm{Ca}^{2+}\right)$ to form ionic cross-links responsible for storage hardening and leading to increased plasticity number and viscosity. Following this mechanism, Gan and Ting investigated the influence of main group mono-and divalent cations as well as transition metal ions on storage hardening due to reactions of carboxylate groups from the rubber chains. According to these authors, $\mathrm{Na}^{+}$and $\mathrm{K}^{+}$it do not affect storage hardening, but $\mathrm{Ca}^{2+}$ and $\mathrm{Mg}^{2+}$ reduce it, which is assigned to these ions blocking the carboxylate groups and preventing other reactions eventually leading to chain crosslinking.

Neither latex coagulation nor centrifugation is able to fully remove the ions from rubber and significant amounts may end up within the solid rubber. This may account for observed variations in the mechanical properties of the latex, as well as for the unique properties of natural rubber.

Figure 1 shows the bright-field image and elemental maps of $\mathrm{C}, \mathrm{O}, \mathrm{Ca}, \mathrm{Al}$ and $\mathrm{N}$ from centrifuged natural rubber latex. ${ }^{22}$ The map of calcium has a profile very similar to the distribution C map, showing that this element is quite compatible with the rubber matrix that must therefore contain binding sites for calcium. The elemental maps of
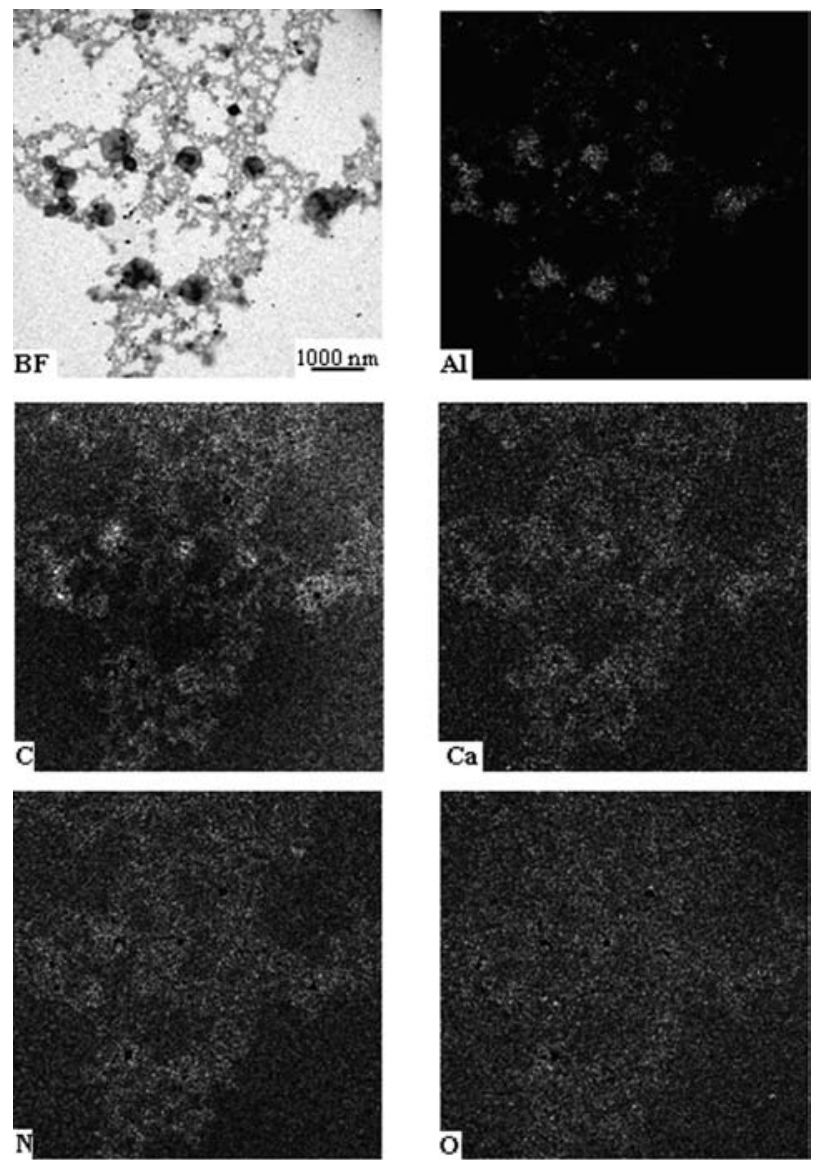

Figure 1. Bright-field and elemental images of natural rubber latex film. Scale bar is $1000 \mathrm{~nm}$.

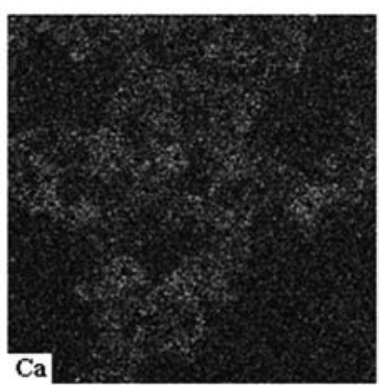

$\mathrm{N}$ and $\mathrm{O}$ show these elements well distributed in the film, more than $\mathrm{Ca}, \mathrm{Al}$ and other mineral ions. Some particles show a dense accumulation of $\mathrm{Al}$ and depletion of $\mathrm{C}$, thus they are formed by inorganic constituents. Moreover, these particles are strongly attached or occluded within rubber resisting dialysis, as shown in Figure 2. Rubber-particle interfaces accumulate non-rubber organic compounds, especially proteins, making particles compatible with rubber, and mechanically reinforcing it.

When natural rubber particles are dried and aged, calcium sulfate crystallites are slowly formed, depending the presence of ammonia as can be seen in Figure 3. ${ }^{23}$

So, the "mistery" of natural rubber is at least partly due to ionic crosslinks mediated by calcium ions and to the presence of crystalline nanoparticles strongly adherent to the rubber phase.

\section{Natural Rubber, Microscopy and Microanalysis $^{22-25}$}

The variability of natural rubber latex requires a continuing effort of analysis and characterization, to avoid process and product undesirable variations and to
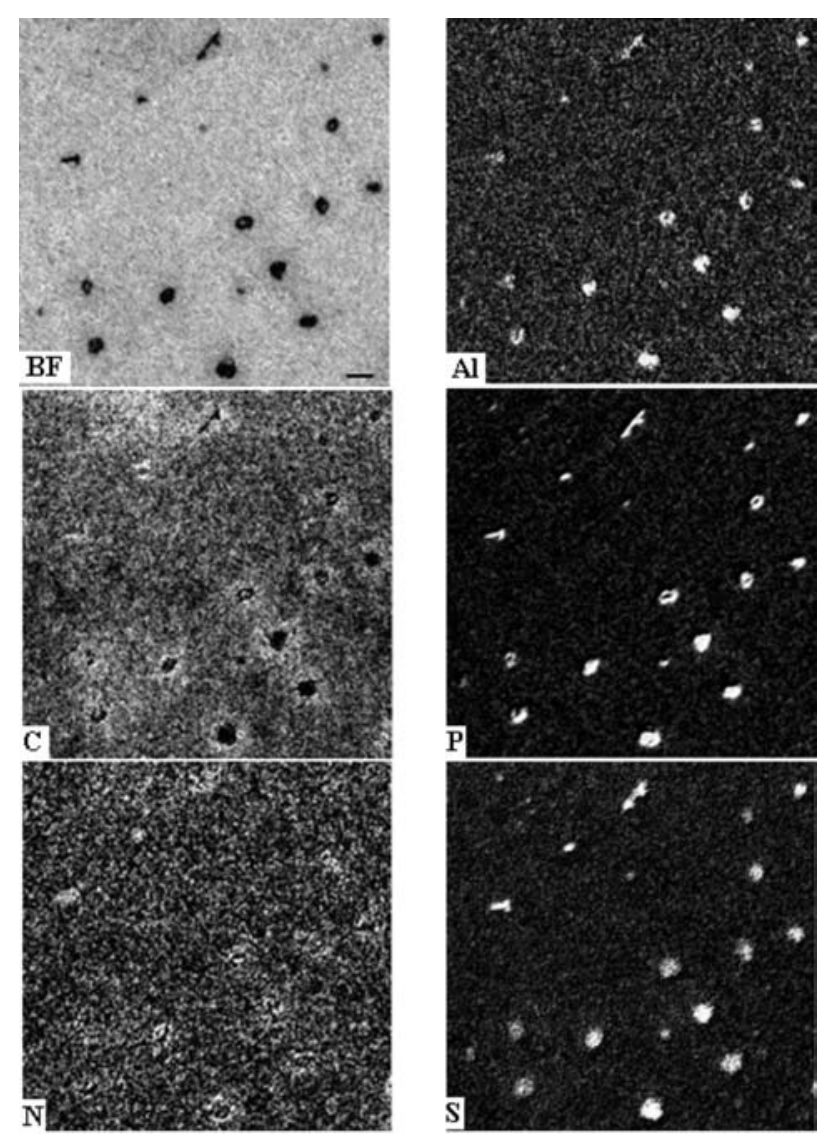

Figure 2. Bright-field and elemental images of dialyzed natural rubber latex film. Scale bar is $200 \mathrm{~nm}$.

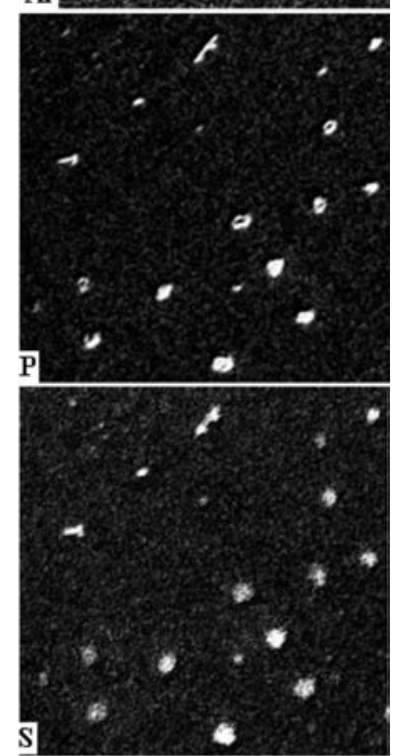

S images of dialyzed natural rubber 

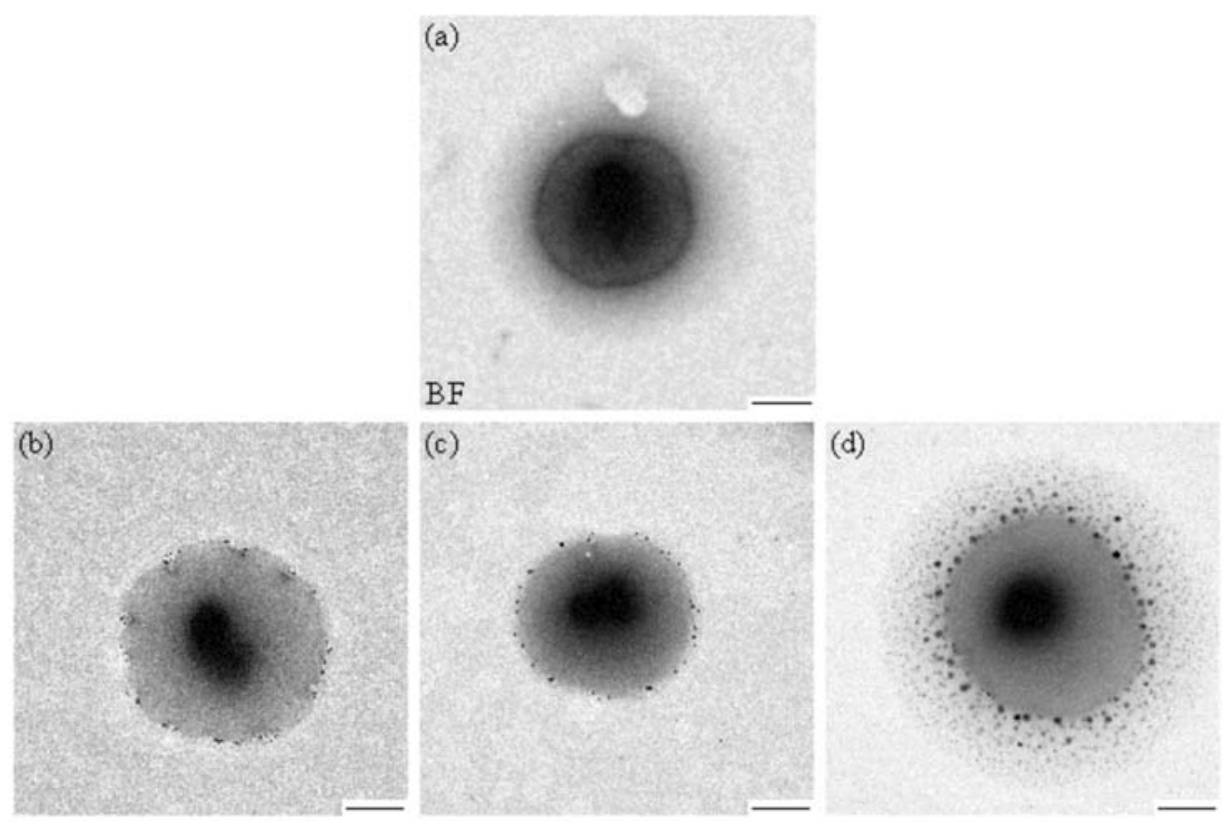

Figure 3. Bright field TEM images of non-ammonia natural rubber particles dried in air for: 2 hours (a), and 1 week (b-d). An electron-rich membrane is visible in the 2-hour-old particle; small particulate materials are seen in the 1-week-old particles. Bar scale $=500 \mathrm{~nm}$.

help directing material from different origins (e.g. clones) to specific applications. The contribution of this group to knowledge on the unique properties of natural rubber largely relied on microscopy and microanalysis techniques, especially analytical electron microscopy and scanning probe microscopy together with the determination of mechanical, swelling and other macroscopic properties allied to calculations on model systems..$^{26-29}$

These techniques have a large potential for microanalysis but they are still unfamiliar to most chemists. The combined use of atomic force microscopy and analytical transmission electron microscopy showed that sites bearing calcium ions are stiffer than sites depleted from calcium, evidencing $\mathrm{Ca}^{2+}$ cross-linking role. This result and the observation of nanosized particles strongly adherent to the polymer are two completely unexpected results, if we consider that natural rubber is just cis-polyisoprene. Thus, natural rubber is best described as a complex nanocomposite compound formed by self-assembled polyisoprene, protein, phospholipids (that in turn hydrolyze forming other surfactants) together with a host of inorganic particles that are by themselves rather complex.

\subsection{Nanocomposites from natural rubber ${ }^{30}$}

Natural rubber latex is also a good starting material for making nanocomposites with a host of other waterdispersed particles, e.g. clay, using a mild dispersion shear blending process. Results of X-ray diffraction (XRD) and transmission electron microscopy (TEM) show that clay particles are well dispersed in the dry latex and the exfoliated platelets have a preferential orientation, forming translucent solids. These show tensile mechanical properties analogous to those obtained with vulcanized rubber as well as an increased solvent resistance, which can only be expected considering that there is significant adhesion between clay lamellae and rubber. Natural rubber properties are thus being strongly modified producing unprecedented combinations of properties. Clay platelets are oriented within the cast films and there is strong adhesion at the rubber-clay interface, assigned to electrostatic interaction between clay, rubber and the dry serum counter-ions. This adhesion creates the possibility to prepare nanocomposites with highly variable mechanical properties just by changing the clay content. These ideas were further extended to other systems based on synthetic latexes. ${ }^{31}$

\subsection{Electrostatic adhesion}

Adhesion between chemically dissimilar solids is not often observed for fundamental reasons, especially the large solid-solid interfacial tensions involved that in turn derive from the fundamental characteristics of van der Waals and other intermolecular interactions. However, this difficulty was recently overcome in many cases, by mixing particulate solids within aqueous media and drying the resulting dispersion, as described in the previous section. The first successful example was natural rubber-montmorillonite clay nanocomposite ${ }^{30}$ and this was already extended to a number of materials derived from 
other polymers and inorganic particles. In a model study, ${ }^{32}$ transmission electron (TEM) and scanning probe (SPM) microscopy provided evidence for strong adhesion between the following pairs of organic and inorganic nanoparticles: Stöber silica and poly (styrene-co-butyl acrylate-co-acrylic acid) (SA) latex, calcium montmorillonite and the same latex, titanium dioxide and another SA latex. Adhesion was observed even though the particles in each pair are highly dissimilar and thus expected to have a high interfacial tension. Bulk or aggregate particle nanohybrids were obtained by drying mixed aqueous dispersions at different particle concentrations and they were examined using bright-field and energy-filtered imaging in the TEM as well as intermittent contact and phase-contrast SPM techniques. Association between silica, clay or $\mathrm{TiO}_{2}$ with latex particles was observed under several conditions, while partial particle segregation was also observed. A general mechanism for the formation of hybrid or composite monoliths was then proposed, based on the action of capillary forces during the drying process followed by electrostatic interactions within the dry solid, between negative particles and cationic domains formed by dry serum solutes. Using this model, calculated electrostatic adhesion energy between dissimilar particles can be used to explain previous literature data. This mechanism is suitable for making hybrid monoliths out of nanosized particles and it should be extended to a number of other renewable materials as well as to abundant minerals.

\section{Latex Blends}

An especially interesting case of application of the electrostatic adhesion mechanism is in the case of latex blends that are mixtures of two or more different types of polymer latex..$^{33}$ They are especially interesting because the interfacial properties can be controlled in many different ways, depending on the dispersant and stabilizers used in the blended latex dispersions. Greatest interest in latex blends is currently in coating applications, combining low- $\mathrm{T}_{\mathrm{g}}$ and high- $\mathrm{T}_{\mathrm{g}}$ polymers, resulting on coatings with good film-forming abilities and high mechanical strength. This represents a very useful alternative for the use of volatile organic solvents as coalescing aids in the paint formulations. . $^{34,35}$

This method has some advantages, which are not present in other blend-making techniques, which can help in achieving fine dispersion and adhesion between the phases. The presence of surfactants adsorbed at the interfaces can decrease the interfacial tension reducing the coarsening rate of the domain structures while forming structures that contribute to electrostatic adhesion. During water evaporation in the drying process, counter-ions and ionic surfactant accumulate at the interface between polymer charged particles ${ }^{36}$ contributing to the union of the phases, improving adhesion and consequently the mechanical properties of the blends. Latex particles dried from aqueous dispersions accumulate counter-ions at the interfaces ${ }^{37,38}$ that contribute to electrostatic adhesion ${ }^{32}$ and add up to van der Waals interactions and hydrogen bonds that should produce significant cohesion in latex blends also. This creates a large and still untapped possibility for enriching or modifying blends with a variety of other types of water-dispersible particles, contributing to alreadyexisting techniques for making functional materials.

\section{A Paradigm for New Materials from Renewable Resources}

Polymer materials design is often limited by mixing and compatibility issues, while attempting to combine different phases into the desired structures. Success has been achieved by using growingly sophisticated synthetic chemical techniques, ${ }^{39-42}$ self-assembly ${ }^{37,38,43}$ and even nanofabrication but designing for large-scale production requires the use of raw materials that are not subject to environmental or economic constraints. Work done with natural rubber has now been extended to other systems, showing that electrostatic adhesion is an effective way to self-assemble highly incompatible polymer and inorganic phases, relying on their surface characteristics only and with little dependence from bulk properties, without doing any chemical modification of the clay or the polymer and forming nanocomposites with tunable and unprecedented properties led to the re-examination of electrostatic adhesion.

These findings help us to understand previous results on particle self-assembly forming colloidal crystals and macrocrystals, while revealing a new, broad-scope strategy that can be explored by materials designers, helping them to overcome well-known mixing limitations while using "green" procedures and relying on the role of water as a cohesion mediating agent. This is very well adapted to combining materials of natural origin, including lignin, cellulose, protein fibers and starch, among themselves or with inorganic particles of various origins and shapes.

To make the examination of these complex systems it has been necessary to develop especial analytical TEM techniques and this group has recently made two methodological contributions in this direction, both based on the use of energy-filtered TEM (EFTEM). The first was the demonstration that thick cuts may be imaged producing significant information on component packing in large particle aggregates ${ }^{44}$ and the other was a technique for molecular mapping ${ }^{26}$ that allows the distinction of domains 
formed by different polymers, based on differences in their electron energy-loss spectra in the low energy-loss region $(0-80 \mathrm{eV})$.

\section{Conclusions}

As long as the world will continue to move on wheels, natural rubber is bound to persist as an important contribution of the Amazon forest to human life. Its history contains many lessons on the importance of continuing scientific investigation devoted to the forest and to its contents, using the most powerful research tools available at any given time. This has contributed to understand natural rubber unique properties and to develop new rubber-based materials together with the associated new processes creating a number of possibilities for innovation.

\section{Acknowledgments}

This project is supported by Petrobras (Rede Temática de Nanotecnologia). The authors acknowledge support of FAPESP, CNPq (Millenium Institutes and INCT Program), FINEP and CAPES at different times.

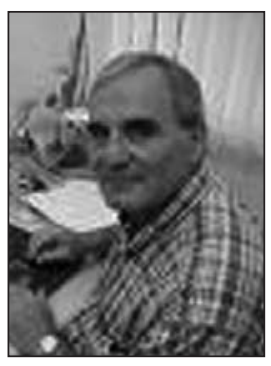

Fernando Galembeck holds Chemistry BSc (1964) and PhD (1970) degrees from Universidade de São Paulo (USP) and was a post-doc in the Universities of Colorado and California (Davis). He taught at USP and Universidade Estadual Paulista (Unesp, Araraquara) and he has been in Universidade Estadual de Campinas (Unicamp) since 1980 having served as the Head of the Institute of Chemistry and university General Coordinator (vice-rector). He also served in many governmental agencies (Fapesp, Capes, $C N P q$, MCT), learned societies ( $S B Q, S B P C, S B M M$, IACIS, ABC), journals (Química Nova, JBCS, JCIS, AABC, $B C C S)$ and as a consultant to a number of companies, having received many prizes.

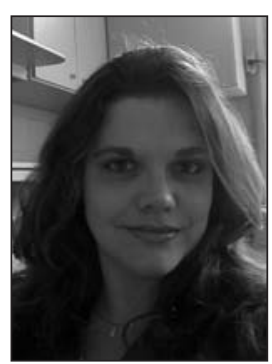

Márcia Maria Rippel received her $B S c$ degree in chemistry from the Universidade Estadual de Campinas (Unicamp) in 1995 and concluded her PhD in physical-chemistry in Prof. Fernando Galembeck group at Unicamp in 2005. She is a consultant and researcher in natural rubber and other biopolymers. Since 2005 works as a researcher in the group of Professor Fernando
Galembeck, in which she researches biopolymers nanocomposites.

\section{References}

1. Van Beilen, J. B.; Poirier, Y.; Trends Biotechnol. 2007, 25, 522.

2. Mooibroek, H.; Cornish, K.; Appl. Microbiol. Biotechnol. 2000, 53,355 .

3. http://www.rubberstudy.com/statistics-quarstat.aspx, accessed in June 2009.

4. De Rodriguez, D. J.; Ângulo-Sanchez, J. L.; Rodriguez-Garcia, R.; J. Polym. Environ. 2006, 14, 37.

5. Ricardo, N. M. P. S.; Feitosa, J. P. A.; Silveira, E. R.; Neto, M. A.; Polym. Bull. 2001, 46, 107.

6. Greve, H-H. In Ullmann's Encyclopedia, VCH Publishers: Deerfield Beec, 1993, 23A.

7. Cyr, D. R. In Kirk-Othmer Encyclopedia of Chemical Technology, Wiley-Interscience: New York, 1991, vol. 20, p. 468.

8. http://www.incaper.es.gov.br/congresso_seringueira, accessed in November 2007.

9. http://www.iac.sp.gov.br/Centros/Centro_cafe/seringueira, accessed in March 2009.

10. http://www.globorural.globo.com, accessed in January 2009.

11. Rippel, M.M.; Bragança, F. C. Quim. Nova 2009, 32, 818.

12. http://www.borrachanatural.agr.br, accessed in October 2007.

13. http://www.yulex.com/index.html, accessed in November 2007.

14. http://www.iac.sp.gov.br/centros/centro_cafe/seringueira/desc. htm, accessed in June 2009.

15. http://portalamazonia.globo.com/artigo_amazonia_ az.php?id=114, accessed in June 2009.

16. http://www.borrachanatural.agr.br/borrachanatural.php, accessed in June 2009.

17. http://www.ced.ufsc.br/emt/trabalhos/borracha/borracha/ extrativismo_arquivos/paulomorceli.pdf, accessed in December 2008.

18. Tanaka, Y. Rubber Chem. Technol. 2001, 74, 355.

19. Sethuraj, M. R.; Mathew, N. M.; Natural Rubber: Biology, Cultivation and Technology, Elsevier Science: Amsterdam, 1992.

20. Burfield, D. R.; Gan, S. N.; Polymer 1977, 18, 607; Burfield, D. R.; Gan, S. N.; J. Polym. Sci. Polym. Chem. 1977, 15, 2721.

21. Kawahara, S.; Kakubo, T.; Sakdapipanich, J. T.; Isono, Y.; Tanaka, Y.; Polymer 2000, 41, 7483.

22. Rippel, M. M.; Leite, C. A. P.; Galembeck, F. Anal. Chem. 2002, 74, 2541.

23. Rippel, M. M.; Lee, L-T.; Leite, C. A. P.; Galembeck, F. J.; J. Colloid Interface Sci. 2005, 288, 449.

24. Rippel, M. M.; Lee, L-T.; Leite, C. A. P.; Galembeck, F.; J. Colloid Interface Sci. 2003, 268, 330. 
25. Rippel, M. M.; Leite, C. A. P.; Lee, L-T.; Galembeck, F.; Colloid Polym. Sci. 2005, 283, 570.

26. Linares, E. M.; Leite, C. A. P.; Valadares, L. F.; Silva, C. A.; Rezende, C. A.; Galembeck, F.; Anal. Chem. 2009, 81, 2317.

27. Braga, M; Costa, C. A. R.; Leite, C. A. P.; Galembeck, F.; J. Phys. Chem. B 2001, 105, 3005.

28. Santos, J. P.; Corpart, P.; Wong, K.; Galembeck, F.; Langmuir 2004, 20, 10576.

29. Teixeira-Neto, E.; Kaupp, G.; Galembeck, F.; Colloids Surf., A 2004, 243, 79; Teixeira-Neto, E.; Kaupp, G.; Galembeck, F.; J. Phys. Chem. B 2003, 107, 14255.

30. Valadares, L. F.; Leite, C. A. P.; Galembeck, F.; Polymer 2006 , 47, 672 .

31. Bragança, F. C.; Valadares, L. F.; Leite, C. A. P.; Galembeck, F.; Chem. Mater. 2007, 19, 3334.

32. Valadares, L. F.; Linares, E. M.; Bragança, F. C.; Galembeck, F.; J. Phys. Chem. C 2008, 112, 8534.

33. Paul, D. R.; Newman, S.; Polymer blends, vol.1, Academic Press: London, 1978.

34. Spiro, J. G.; Farinha, J. P. S; Winnik, M. A.; Macromolecules 2003, 36, 7791.

35. Lepizzera, S.; Lhommeau, C.; Dilger, G.; Pith, T.; Lambla M.; J. Polym. Sci., Part B: Polym. Phys. 1997, 35, 2093.
36. Feng, J.; Winnik, M. A.; Siemiarczuk, A.; J. Polym. Sci., Part B: Polym. Phys. 1998, 36, 1115.

37. Cardoso, A. H.; Leite, C. A. P.; Galembeck, F.; Langmuir 1998, 14, 3187

38. Cardoso, A. H.; Leite, C. A. P.; Galembeck, F.; Langmuir 1999, $15,4447$.

39. Kim, W. S.; Jia, L.; Thomas, E. L.; Adv. Mater. 2009, $21,1921$.

40. Gido, S. P,; Schwark, D. W.; Thomas, E. L.; Gonçalves, M. D.; Macromolecules 1993, 26, 2636.

41. Mosnacek, J.; Yoon, J. A.; Juhari, A.; Koynov, K; Matyjaszewski, K.; Polymer 2009, 50, 2087.

42. Plichta, A.; Li, W. W.; Matyjaszewski, K.; Macromolecules 2009, 42, 2330.

43. Galembeck, A; Costa, C. A. R.; da Silva MDVM; Galembeck F.; J. Colloid Interf. Sci. 2001, 234, 393.

44. Valadares, L. F.; Bragança, F. C.; da Silva, C. A.; Leite, C. A. P.; Galembeck, F. J. Colloid Interf. Sci. 2007, 309, 140.

Received: June 23, 2009

Web Release Date: June 29, 2009

FAPESP helped in meeting the publication costs of this article. 